\title{
Power flow management of triple active bridge for fuel cell applications
}

\author{
Nageswara Rao Kudithi, Sakda Somkun \\ School of Renewable Energy and Smart Grid Technology, Naresuan University, Thailand
}

\begin{tabular}{|c|c|}
\hline Article Info & ABSTRACT \\
\hline Article history: & The power conditioning circuits which are used in fuel cell systems should \\
\hline Received Nov 23, 2018 & $\begin{array}{l}\text { carefully be designed to prolong the life span of the system, for the reason of } \\
\text { the dynamic nature, such that the unexpected and extreme changes in load }\end{array}$ \\
\hline Revised Jan 22, 2019 & decreases the life of the fuel cells. This paper presents the triple active bridge \\
\hline Accepted Mar 3, 2019 & $\begin{array}{l}\text { (TAB) and its average small signal modelling, which is used for design of the } \\
\text { system controllers for stable operation. The extended symmetrical optimum }\end{array}$ \\
\hline Keywords: & $\begin{array}{l}\text { method is used for realized the proportional integral (PI) controller, to } \\
\text { control the output/Load voltage and power flow in the fuel cell/Source with a }\end{array}$ \\
\hline DC DC Converters & guaranteed minimum phase margin for the system with a variable process \\
\hline Extended symmetric optimum & gain in addition to other accepted desired performances. This method ensures \\
\hline Fuel cell & $\begin{array}{l}\text { he maximum phase margin at a minimum required value at the desired gain } \\
\text { crossover frequency with a compromise between system's peak overshoot, }\end{array}$ \\
\hline Triple active bridge (TAB) & $\begin{array}{l}\text { rise time and settling time. This model and this approach helps in designing } \\
\text { TAB suitable for healthy and uninterrupted fuel cell power generation } \\
\text { systems as a part of a renewable /clean energy system. MATLAB/Simulink } \\
\text { is used to simulate the proposed controllers with TAB. }\end{array}$ \\
\hline
\end{tabular}

Copyright (C) 2019 Institute of Advanced Engineering and Science. All rights reserved.

\section{Corresponding Author:}

Sakda Somkun,

School of Renewable Energy and Smart Grid Technology,

Naresuan University, Phitsnanulok, Thailand.

Email: sakdaso@nu.ac.th

\section{INTRODUCTION}

Recently, demand for the renewable or clean energy systems, due to the global warming and acid rains [1]. At present different types of electrical energy generation systems are available for both portable and residential applications. But one of the most favorable alternatives stays as the fuel cell, which provide energy with no pollution or environment degradation[2]. In addition, it's provide predictable amounts of instantaneous energy, which is not possible with other energy generation systems. When a fuel cell as an energy generation system for the load/grid it should connected to the storage system like battery or supercapacitors [3, 4], which stores energy when in excess and delivers it on demand to sustain the load/grid stability to increase the fuel cell life span [5-7]. Therefore, power electronic interfaces are used to isolated the fuel cell with the load/grid, while an additional storage device is commonly adopted to supply power in transient conditions [8-10]. In such systems, when storing and retrieving the energy, the power conditioning circuits are involved as an integral part of the system[11, 12].

Since the dual active bridge (DAB) topology $[13,14]$, and proposed TAB employing a three winding transformer with high frequency [15-17], as shown in Figure 1. The transformer not simply merge and interchanges energy from/to all the ports, although also matches the different voltage levels and offers the full isolation between all the ports [18-20]. A power flow be able to accomplish bi-directionally by varying the phase shift of the $\mathrm{AC}$ voltages produced through full-bridge cell from respective ports. In this storage (Supercapacitors) system behave as a power filter to soft the flow of the power in source (Fuel Cell), 
and equal to average load power noticed, toward to select the limits of primary source for the whole system, no need to inspect the peak power [21,22].

In this paper proposes the modelling, controlling, and simulation of the power conditioning circuit, and an optimization technique for the topology illustrated in Figure 1 with the purpose of power flow management with the overall system losses should be minimized, where ensured circulating power within the DC-DC converter equals to zero. In addition, the average small signal model and the related controllers are developed for TAB. Hence the converter which is identified with Galvanic Isolation, Power Flow in Bidirectional, great Power Density, high Efficiency, and including Zero Voltage Switching (ZVS) capability is a suitable candidate for the DC-DC conversion of low voltage fuel cell power generation system. Furthermore, these systems can also be employed in vehicular technologies [23-26].

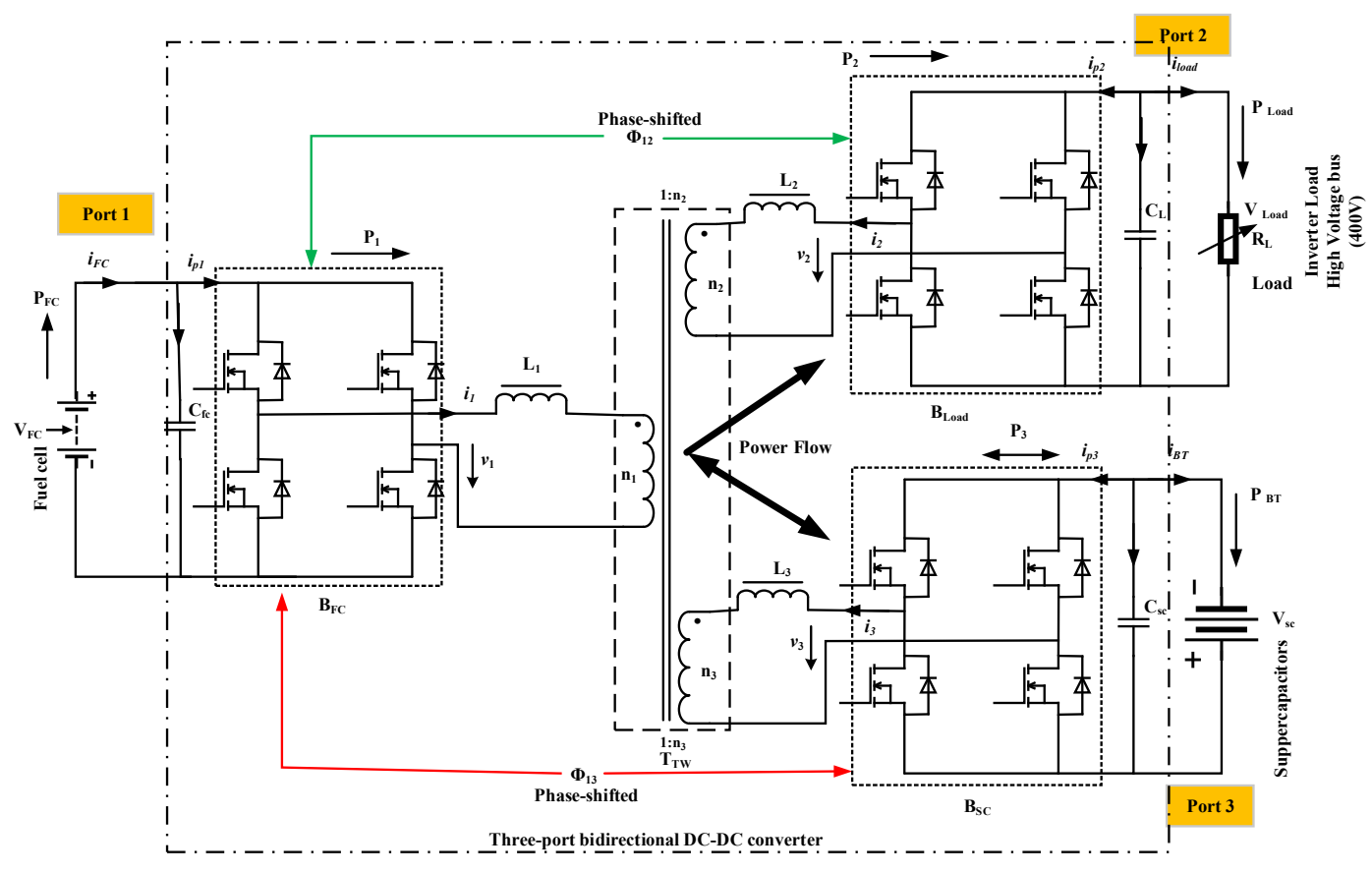

Figure 1. Three port DC-DC converter topology

\section{CIRCUIT DESCRIPTION}

The TAB topology as shown in Figure 1 have a fuel cell as source for the system with full bridge $\left(\mathrm{B}_{\mathrm{FC}}\right)$ cell, which converts an alternating voltage $v_{1}$ from the DC voltage $V_{\mathrm{fc}}$, this voltage $v_{1}$ is given to three winding high frequency transformer $\left(\mathrm{T}_{\mathrm{TW}}\right)$, this is connected to another two full bridge cells with Load $\left(\mathrm{B}_{\mathrm{LOAD}}\right)$ port, and storage $\left(\mathrm{B}_{\mathrm{SC}}\right)$ port, here storage as supercapacitors, this full bridges are functioning with DC feeding voltages to load port and from/to the supercapacitors port. The voltages $v_{2}^{\prime}$ and $v_{3}^{\prime}$ are rectified by full-bridges of $\mathrm{B}_{\mathrm{LOAD}}$ and $\mathrm{B}_{\mathrm{SC}}$, respectively. TAB is the heart of the system, it provides the interface between the source to inverter load, and storage device. It should match the specific requirements of the overall system, for instant, galvanic isolation, bi-directional power flow, ability to equivalent dissimilar voltages, and quick response to fulfill the fleeting demand from the load.

Figure 1, shown the recommended the TAB, with the voltage levels of port 1, and 3 are low voltage buses $50 \mathrm{~V}$ and $48 \mathrm{~V}$ respectively, and port 2 is high voltage bus $400 \mathrm{~V}$. Here, representation of voltages from full bridge cells are $u_{1}, u_{2}^{\prime}$, and $u_{3}^{\prime}$ along $50 \%$ duty cycle, to govern the power flow. All the parameters and variables are taken from equivalent circuits shown in figure 2 , variables of port-2 and port-3 are referred to the primary side bridge $\left(\mathrm{B}_{\mathrm{FC}}\right)$, and as follows $\mathrm{L}_{2}=L_{2}^{\prime} / \mathrm{n}_{2}, \mathrm{~V}_{2}=V_{2}^{\prime} / \mathrm{n}_{2}, \mathrm{u}_{2}=u_{2}^{\prime} / \mathrm{n}_{2}, \mathrm{i}_{2}=i_{2}^{\prime} \cdot \mathrm{n}_{2}$ for port 2 and $\mathrm{L}_{3}=$ $L_{3}^{\prime} / \mathrm{n}_{3}, \mathrm{~V}_{3}=V_{3}^{\prime} / \mathrm{n}_{3}, \mathrm{u}_{3}=u_{3}^{\prime} / \mathrm{n}_{3}, \mathrm{i}_{3}=i_{3}^{\prime} \cdot \mathrm{n}_{3}$ for port 3 . Where $v_{2}^{\prime}$ and $v_{3}^{\prime}$ are the DC voltage levels of the port 2, and 3 , and currents $i_{1}, i_{2}^{\prime}$, and $i_{3}^{\prime}$ are belongs to the leakage inductance. Here, transformer magnetizing inductance $\left(\mathrm{L}_{\mathrm{m}}\right)$ is not conceder for this modeling. And transformer has two important functions, such as it is provide electrical isolation between all three buses and its can be harmonized the dissimilar voltage levels by selecting suitable turns ratios in the respective winding.

Power flow management of triple active bridge for fuel cell application (Nageswara Rao Kudithi) 
The converter power flow is not depending on the port voltages but it is dependent on phase displacement between the any of the two bridges, here the control signal phase shifts are symbolized as $\phi_{12}$ which is the square wave voltage sources $\mathrm{u}_{1}$ and $\mathrm{u}_{2}$ generated by two full-bridge cells at Port-1 and 2 , and $\phi_{13}$ symbolized the phase displacement between $u_{1}$ and $u_{3}$ as shown in figure 3 . And $\phi_{12}$ and $\phi_{13}$ are denoted positive value when $\mathrm{u}_{1}$ is leading to $\mathrm{u}_{2}$ and/or leading to $\mathrm{u}_{3}$. Equivalent circuit of the transformer, which make things easier for the power flow analysis with help of Y and $\Delta$-type circuit was projected in[27]. In this equivalent circuit, the voltages $\mathrm{u}_{1}, \mathrm{u}_{2}$, and $\mathrm{u}_{3}$ signifies the voltages produced through bridges $\mathrm{B}_{\mathrm{FC}}, \mathrm{B}_{\mathrm{LOAD}}$, and $\mathrm{B}_{\mathrm{SC}}$ respectively, and the leakage inductances are expressed in terms of inductances $\mathrm{L}_{12}, \mathrm{~L}_{13}, \mathrm{~L}_{23}$. To define the converter power flow, the fundamental system becomes three square-wave voltage sources with help of equivalent model, and a grid of inductors are exchange the sources energy throughout the system. The phase shifted by $\emptyset_{12}$ and $\emptyset_{13}$ in voltages $v_{2}^{\prime}$ and $v_{3}^{\prime}$ with respect to the $v_{1}$, respectively. The phase displacement is negative, when the output voltage leads the reference (source) voltage and or else it is positive. The inductors in figure 3 is based on a $\Delta$-model illustration and inductors network is extracted from the transformer of the system [27].
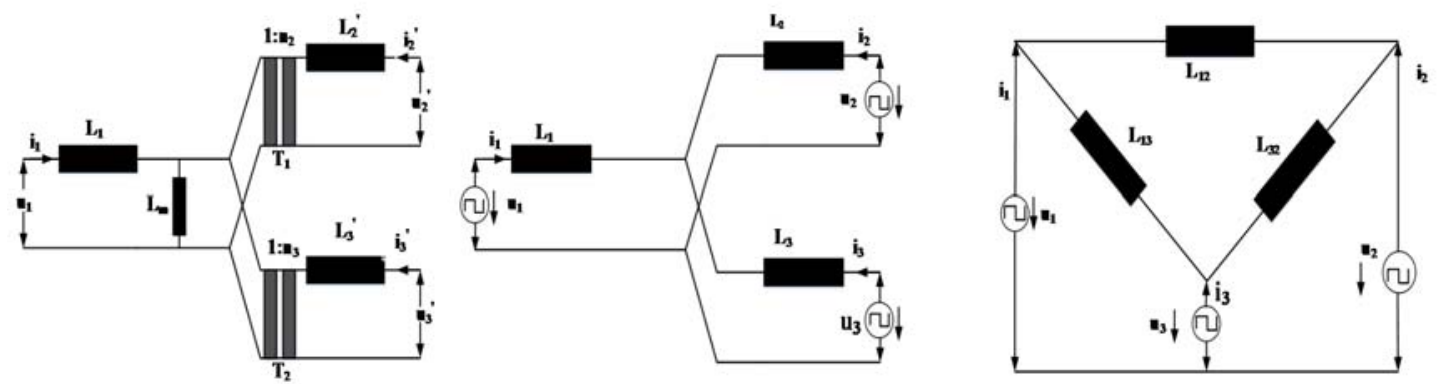

Figure 2. Y-and, $\Delta$-type equivalent circuit of the primary-referred three winding transformer.

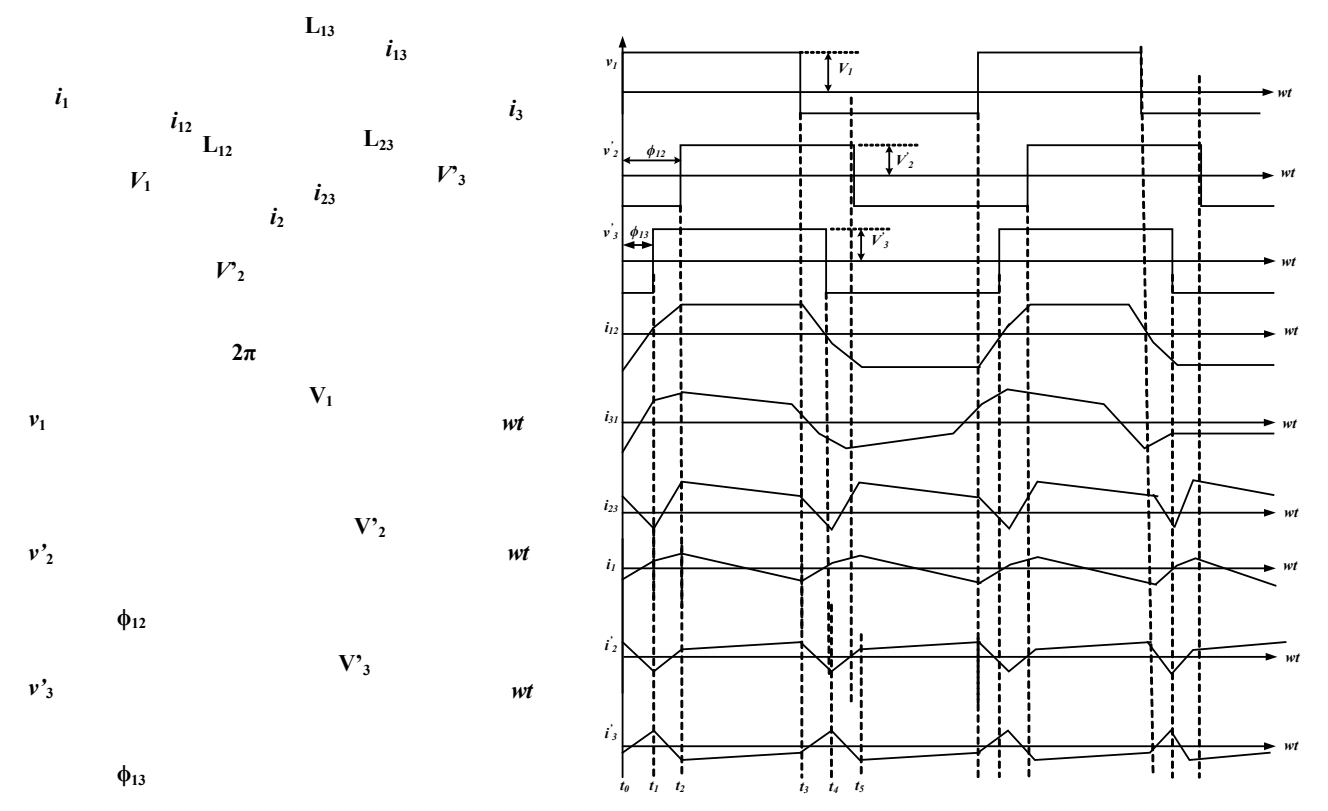

Figure 3. Equivalent circuit and voltage and current waves at transformer winding end

A TAB, as extension of the dual active bridge (DAB) circuit [28], so it shows the patterns of three two port circuits, the inductive network with voltage and current waves at transformer windings with respect to the bridge phase displacement and power transferred in the whole system to be express in [28-30]. 


$$
\left.\begin{array}{c}
P_{12}=\frac{V_{1} V_{2}}{n_{2} 2 \pi f_{s} L_{12}} \emptyset_{12}\left(1-\frac{\emptyset_{12}}{\pi}\right) \\
P_{23}=\frac{V_{2} V_{3}}{n_{2} n_{3} 2 \pi f_{s} L_{23}}\left(\emptyset_{13}-\emptyset_{12}\right)\left(1-\frac{\left|\emptyset_{13}-\emptyset_{12}\right|}{\pi}\right) \\
P_{31}=\frac{V_{1} V_{3}}{n_{3} 2 \pi f_{s} L_{13}} \emptyset_{13}\left(1-\frac{\emptyset_{13}}{\pi}\right)
\end{array}\right\}
$$

where

$$
\begin{aligned}
& \mathrm{V}_{1}=\text { Fuel cell voltage, } \\
& \begin{array}{c}
\mathrm{V}_{2}=\text { Load voltage, } \\
\mathrm{V}_{3}=\text { Storage Device voltage, }
\end{array} \\
& \begin{array}{l}
\emptyset_{13} \text { and } \emptyset_{12} \text { Phase shifts between the bridges } \mathrm{B}_{\mathrm{FC}} \text {, to } \mathrm{B}_{\mathrm{Load}} \text {, and } \mathrm{B}_{\mathrm{SC}} . \\
\mathrm{V}_{\mathrm{SC}}
\end{array} \\
& f_{\mathrm{s}}=\text { switching frequency. }
\end{aligned}
$$

With the delta-model, the power delivered by each port equivalent to integration of the power flows over any of the two related branches (inductors). For lossless converter system, they are

$$
\begin{aligned}
& \left.\begin{array}{c}
P_{1}=P_{12}-P_{31} \\
P_{2}=P_{23}-P_{12} \\
P_{3}=P_{31}+P_{32} \\
\text { and } \\
P_{1}+P_{2}+P_{3}=0
\end{array}\right\} \\
& \text { Where } \quad \mathrm{P}_{1}=\mathrm{P}_{\mathrm{FC}} \quad \text { power delivered by port } 1 \text {, } \\
& \mathrm{P}_{2}=-\mathrm{P}_{\text {Load }} \quad \text { power supplied by port 2, } \\
& \text { (negative sign means the load consumes energy) } \\
& \mathrm{P}_{3}=\mathrm{P}_{\mathrm{SC}} \quad \text { power taken from port } 3
\end{aligned}
$$

Therefore, from the above expressions the two phase shifts are chosen for control the total system power flow. In the view of above equations, the maximum power flow through every indictor is at $\frac{\pi}{2}$ and the absolute value of the phase displacement shall be $\left|\emptyset_{12}\right| \leq \frac{\pi}{2}$ and $-\frac{\pi}{2} \leq\left|\emptyset_{13}\right| \leq \frac{\pi}{2}$, note it in this case $\emptyset_{12}$ should be positive for the all instants because we are using the source as fuel cell.

\section{MODELLING OF THE SYSTEM}

In this section, firstly shows the modelling of fuel cell, Dual Active Bridge (DAB), by using DAB model resolve the Triple Active Bridge (TAB).

\subsection{Fuel cell}

In the literature so many PEM fuel cell models are described based on the thermodynamic and electrochemical expressions. This model considered with constant hydrogen pressure flow into stack of the fuel cell for dynamic operation. Fuel cell output voltage is expressed as [31]

$$
\mathrm{V}_{\mathrm{fc}}=\mathrm{E}-\mathrm{V}_{\mathrm{act}}-\mathrm{V}_{\text {conc }}-\mathrm{V}_{\text {ohm }}
$$

where

$$
\begin{aligned}
& \mathrm{E} \quad-\text { is open circuit fuel cell voltage }\left(\mathrm{V}_{\mathrm{oc}}\right) \\
& \mathrm{V}_{\text {act }} \quad-\text { is activation voltage losses at zero current density }\left(\mathrm{I}_{\mathrm{o}}\right) \\
& \mathrm{V}_{\text {conc }}-\text { is voltage drop due to concentration losses in fuel input } \\
& \mathrm{V}_{\mathrm{ohm}}-\text { is voltage drop of Ohmic losses }
\end{aligned}
$$

From the above expression (3) and based on the polarization cure shown in Figure 4(a) has been observed that a fuel cell can functioned with the linear region while varying the constant internal resistance with respective of output loads. So based on this observation it can be linearized by using the expression below,

$$
\mathrm{V}_{\mathrm{fc}}=\mathrm{E}-\mathrm{R}_{\mathrm{fc}} \mathrm{I}_{\mathrm{fc}}
$$

\footnotetext{
Power flow management of triple active bridge for fuel cell application (Nageswara Rao Kudithi)
} 
where

$\mathrm{R}_{\mathrm{fc}} \quad-$ is linearized resistance

$\mathrm{I}_{\mathrm{fc}} \quad-$ is fuel cell current

So its gives the dynamic operation region of the fuel cell between the lower and upper current limits.

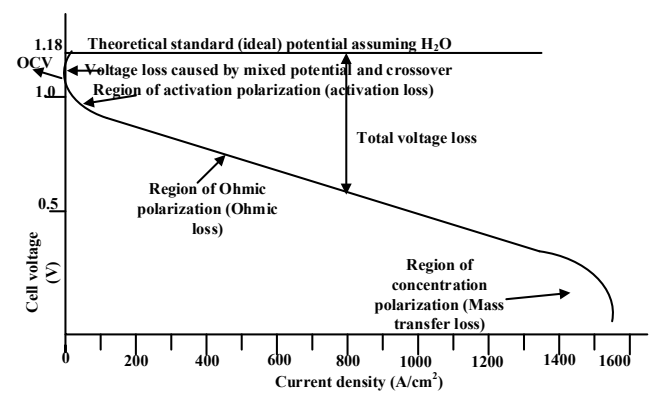

(a)

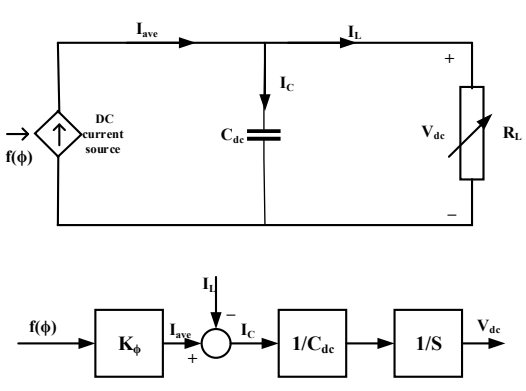

(b)

Figure 4. (a) fuel cell polarization cure (b) modeling circuits of DAB

\subsection{Dual active bridge (DAB)}

The voltage (DC) from the fuel cell is transformed into a square wave voltage with high frequency (non-sinusoidal- AC) at primary winding of the transformer by bridge $\mathrm{B}_{\mathrm{FC}}$ in port-1. After, converted AC voltage is stepped up to high voltage square wave (non-sinusoidal) at secondary winding $\left(\mathrm{n}_{2}\right)$ of the transformer by the bridge $B_{\text {Load }}$ at port- 2 and stepped down to low voltage square wave (non-sinusoidal) at secondary winding $\left(n_{3}\right)$ of the transformer by the bridge $B_{S C}$ at port- 3 with a desired phase shift to meet the required load power. The output of the $\mathrm{B}_{\text {Load }}$ of Port- 2 is a high DC voltage and the $\mathrm{B}_{\mathrm{SC}}$ port-3 is low voltage.

Thanks to the $\Delta$-model representation as shown in Figure 3, the system evaluation is significantly easy. The TAB system model is fragment to three DAB system models. So from [32-34] the averaged model of the DAB is shown in Figure 4(b) which gives the transfer function of the open loop system as

$$
\mathrm{G}_{\mathrm{DAB}}(\mathrm{s})=\frac{\mathrm{K}_{\emptyset}}{\mathrm{C}_{0}} \frac{1}{\mathrm{~s}}
$$

\subsection{Triple active bridge (TAB)}

Thanks to the $\Delta$-model illustration of TAB as shown in figure 3 , its make the much easier analysis of the system. The TAB system is split to three DAB. The perfect operating waveform of the converter are demonstrated. Note that according to the operating point waveforms are differ. The state of ZVS for every bridge cell influenced by the current magnitudes of every switching moment. The summarized waveforms of selected operating point is positive currents at the output voltages of bridge cells $v_{1}, v_{2}^{\prime}$, and $v_{3}^{\prime}$ falling edge and negative currents for the rising edge. For the instant currents in three arms are expressed depending on the above illustration for the reference power,

$$
\left.i_{1}(t)=i_{12}(t)-i_{31}(t) ; \quad i_{2}^{\prime}(t)=-i_{12}(t)+i_{23}(t) ; \quad i_{3}^{\prime}(t)=-i_{23}(t)+i_{31}(t)\right\}
$$

Based on the modeling of DAB, the linearized small signal average model can be resolved for the TAB. The converter is patterned as three current sources (DC) whose amplitudes are ordered by phase displacement of any of the two bridge cells is shown in Figure 5. 

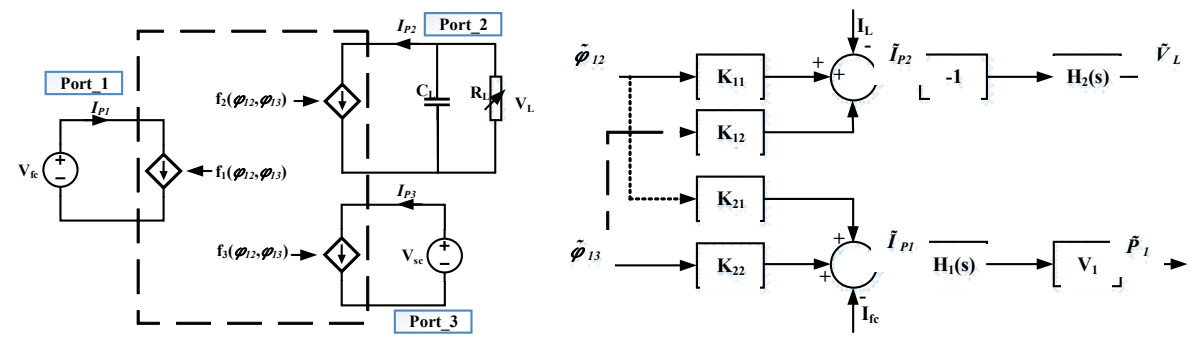

Figure 5. Modeling circuits of TAB.

Each port current is averaged for one cycle of switching, now represent of the average values $i_{P 1}, i_{P 2}$, and $\mathrm{i}_{\mathrm{P} 3}$ by $\mathrm{I}_{\mathrm{P} 1}, \mathrm{I}_{\mathrm{P} 2}$, and $\mathrm{I}_{\mathrm{P} 3}$, correspondingly. Here, the three-port system model only two independent variables are considered for modeling. Therefore, $\mathrm{I}_{\mathrm{P} 3}$ is redundant. The voltages at each port is considered as stable. Since, by using the power flow expressions (1) and (2), we obtain

$$
\left.\begin{array}{c}
I_{P_{1}}=\frac{P_{1}}{V_{1}}=\frac{V_{2}}{n_{2} w L_{12}} \emptyset_{12}\left(1-\frac{\left|\emptyset_{12}\right|}{\pi}\right)+\frac{V_{3}}{n_{3} w L_{31}} \emptyset_{13}\left(1-\frac{\left|\emptyset_{13}\right|}{\pi}\right), \\
I_{P_{2}}=\frac{P_{2}}{V_{2}}=\frac{V_{3}}{n_{2} n_{3} w L_{23}}\left(\emptyset_{13}-\emptyset_{12}\right)\left(1-\frac{\left|\emptyset_{13}-\emptyset_{12}\right|}{\pi}\right)-\frac{V_{1}}{n_{2} w L_{12}} \emptyset_{12}\left(1-\frac{\left|\phi_{12}\right|}{\pi}\right)
\end{array}\right\}
$$

The current source behaves as nonlinear, so to be linearized at the preferred state for a control oriented model,

$$
\tilde{I}=K_{\emptyset_{12}} \widetilde{\emptyset}_{12}+K_{\emptyset_{13}} \widetilde{\emptyset}_{13}
$$
functions

The dynamics of linearization can be resultant with partial differentiation of the current source

$$
K_{\emptyset_{12}}=\left.\frac{\partial I}{\partial \emptyset_{12}}\right|_{\left(\emptyset_{120}, \emptyset_{130}\right)} \text { and } \quad K_{\emptyset_{13}}=\left.\frac{\partial I}{\partial \emptyset_{13}}\right|_{\left(\emptyset_{120}, \emptyset_{130}\right)}
$$

where $\left(\emptyset_{12 o}, \emptyset_{130}\right)$ is the operating point. The resulting small signal representations are

$$
\begin{gathered}
\tilde{I}_{P_{1}}=\frac{V_{2}}{n_{2} w L_{12}}\left(1-\frac{2}{\pi}\left|\emptyset_{120}\right|\right) \tilde{\emptyset}_{12}+\frac{V_{3}}{n_{3} w L_{31}}\left(1-\frac{2}{\pi}\left|\emptyset_{130}\right|\right) \tilde{\emptyset}_{13} \\
\tilde{I}_{P_{2}}=-\left[\frac{V_{3}}{n_{2} n_{3} w L_{23}}\left(1-\frac{2}{\pi}\left|\emptyset_{130}-\emptyset_{120}\right|\right)+\frac{V_{1}}{n_{2} w L_{12}}\left(1-\frac{2}{\pi}\left|\emptyset_{120}\right|\right)\right] \tilde{\emptyset}_{12}+\frac{V_{3}}{n_{2} n_{3} w L_{23}}\left(1-\frac{2}{\pi}\left|\emptyset_{130}-\emptyset_{120}\right|\right) \tilde{\emptyset}_{13}
\end{gathered}
$$

then, we can write it as

$$
\left.\begin{array}{l}
\tilde{I}_{P_{1}}=K_{11} \widetilde{\emptyset}_{12}+K_{12} \widetilde{\emptyset}_{13} \\
\tilde{I}_{P_{2}}=K_{21} \widetilde{\emptyset}_{12}+K_{22} \widetilde{\emptyset}_{13} .
\end{array}\right\}
$$

Where

$$
\left.\begin{array}{c}
K_{11}=-\left[\frac{V_{3}}{n_{2} n_{3} w L_{23}}\left(1-\frac{2}{\pi}\left|\emptyset_{13 o}-\emptyset_{12 o}\right|\right)+\frac{V_{1}}{n_{2} w L_{12}}\left(1-\frac{2}{\pi}\left|\emptyset_{12 o}\right|\right)\right], \\
K_{12}=\frac{V_{3}}{n_{2} n_{3} w L_{23}}\left(1-\frac{2}{\pi}\left|\emptyset_{13 o}-\emptyset_{12 o}\right|\right), \\
K_{21}=\frac{V_{2}}{n_{2} w L_{12}}\left(1-\frac{2}{\pi}\left|\emptyset_{12 o}\right|\right), \quad K_{22}=\frac{V_{3}}{n_{3} w L_{31}}\left(1-\frac{2}{\pi}\left|\emptyset_{13 o}\right|\right),
\end{array}\right\}
$$

From the expressions (8)-(12), we get the matrix format as 
$\left[\begin{array}{l}\tilde{I}_{P_{1}} \\ \tilde{I}_{P_{2}}\end{array}\right]=\left[\begin{array}{ll}K_{11} & K_{12} \\ K_{21} & K_{22}\end{array}\right]\left[\begin{array}{l}\widetilde{\emptyset}_{12} \\ \widetilde{\emptyset}_{13}\end{array}\right]=K_{o}\left[\begin{array}{l}\widetilde{\emptyset}_{12} \\ \widetilde{\emptyset}_{13}\end{array}\right]$

Table 1: Electrical parameters

\begin{tabular}{llll}
\hline Description & Parameter & Description & Parameter \\
\hline Input voltage & $\mathrm{V}_{1}=50 \mathrm{~V}$ & Leakage indactance & $\mathrm{L}_{1}=2.571 \mathrm{uH}$ \\
Output voltage & $\mathrm{V}_{2}=400 \mathrm{~V}$ & Leakage indactance & $\mathrm{L}_{2}=8.851 \mathrm{uH}$ \\
Storage voltage & $\mathrm{V}_{3}=48 \mathrm{~V}$ & Leakage indactance & $\mathrm{L}_{3}=3.241 \mathrm{uH}$ \\
Maximum output power & $\mathrm{P}_{\mathrm{o}}=1000 \mathrm{~W}$ & Switching freqency & $\mathrm{f}_{\mathrm{s}}=20 \mathrm{kHz}$ \\
\hline
\end{tabular}

\section{DESIGN OF THE DUAL-PI}

From the Figure 6, output to control model for TAB converter is offered, the cross-coupling technique is used here. The DAB transfer function is represented with $\mathrm{H}_{2}(\mathrm{~s})$ and $\mathrm{H}_{1}(\mathrm{~s})$ is the transfer function of the LPF with the gain block " $\mathrm{V}_{1}$ " is required since the power is average current times of the voltage at the respective port. The system is considered with two-output and two-input. The Load (output) voltage $\mathrm{V}_{2}$ is controlled by $\phi_{12}$, while the power of fuel cell to be regulated by $\phi_{13}$. And power $\mathrm{P}_{1}$ is computed from quantities of the voltage $\left(\mathrm{V}_{\mathrm{FC}}\right)$ and the average current $\left(\mathrm{I}_{\mathrm{FC}}\right)$ sensed through a Low Pass Filter (LPF).

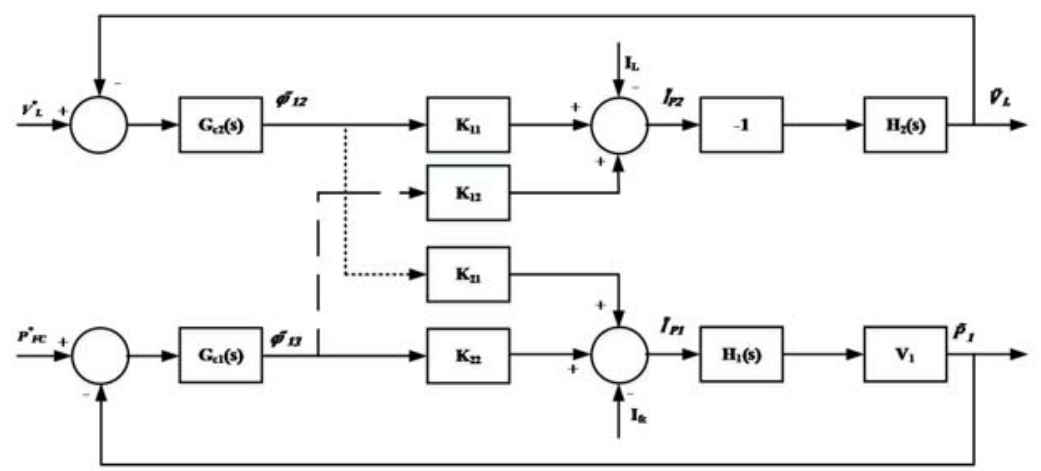

Figure 6. Duel-PI-loop control scheme for the fuel cell with supercapacitors system

Now single phase inverter is considered to be as the load, it should be chosen so as to limit the bandwidth below the double line frequency of the load, which permits a same frequency ripple in the DC-bus voltage. A LPF is presented to regulate the frequency of the ripple current extracted from fuel cell. The time constant $T_{f 1}$ of the LPF is chosen to limit in only a DC current extract from the fuel cell, which is good for the fuel cell membrane.

PI-controller is considered in the system for the stability in the DC-bus voltage under the desired set point. In this design an extended symmetrical optimum method (ESOM) [35] is used in the tuning of the controller.

$$
\left.\begin{array}{c}
G_{V \emptyset_{12}}(s)=-K_{11} H_{2}(s) G_{c 2}(s) \\
G_{P \emptyset_{13}}(s)=K_{22} H_{1}(s) G_{c 1}(s)
\end{array}\right\}
$$

where $G_{c 2}(s)$ and $G_{c 1}(s)$ are the PI controller transfer functions.

and

$$
G_{c 1}(s)=\frac{K_{c 1}\left(1+T_{c 1} s\right)}{s} \text { and } G_{c 2}(s)=\frac{K_{c 2}\left(1+T_{c 2} s\right)}{s}
$$

$$
H_{1}(s)=\frac{1}{1+T_{F 1} s} \quad \text { and } \quad H_{2}(s)=\frac{\mathrm{K}_{\emptyset}}{\mathrm{C}_{0}} \frac{1}{\mathrm{~s}}
$$

here LPF which filters out HF components in $i_{F C}$, where $T_{F 1}$ is the filter's time constant.

Int J Pow Elec \& Dri Syst, Vol. 10, No. 2, June 2019 : 672 - 681 
From the ESOM, PI controller Parameters $\mathrm{K}_{\mathrm{c} 1}, \mathrm{~K}_{\mathrm{c} 2}$ and $\mathrm{T}_{\mathrm{c} 1}, \mathrm{~T}_{\mathrm{c} 2}$ as

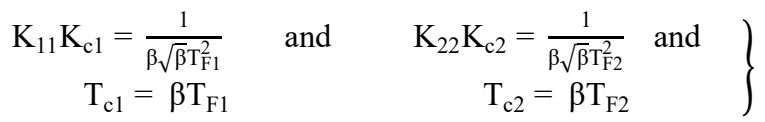

For the TAB controlled power flow by using the controller variables are $\widetilde{\emptyset}_{12}$ and $\widetilde{\emptyset}_{13}$. In additional verses, two degrees of freedom are obtainable to control the overall power transitions in the whole system. In this case considered the two PI controllers are linked and impact each other as shown in figure 6. Interaction should be minimized between the control loops in order to assurance of a fast response to variations in load. So, the bandwidth of the control loops should obey the, fuel cell power control loop $\mathrm{G}_{\mathrm{P} \phi 13}(\mathrm{~s})$ remains agreed lower than that of the load voltage in output control loop $\mathrm{G}_{\mathrm{V} \phi 12}(\mathrm{~s})$. In other words, the control of the power in fuel cell need not to be as fast as the regulation of the output voltage.

Where $\beta$ - is a parameter chosen between 4 and 16 based on required system performance such as rise time, peak overshoot, and settling time. When $\beta<4$ the phase margin $\emptyset_{r M}<36^{\circ}$ which is too small and when $\beta>16$ the phase margin $\emptyset_{r M}>60^{\circ}$ where such high values are not necessary. In this simulation the parameter $\beta$ is chosen as 6 for a maximum phase margin of $45^{\circ}$ of the open-loop system.

The open-loop (OL) and closed loop (CL) bode diagrams are as shown in the Figure 7(a) and (b). It can found that the maximum phase margin of $48.2^{\circ}$ and $16.6^{\circ}$ is given by the controller at $6.97 \mathrm{~Hz}$ and 3.23 $\mathrm{Hz}$ with the low-pass filters.

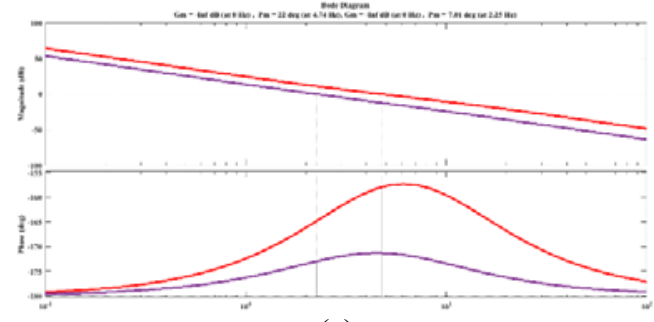

(a)

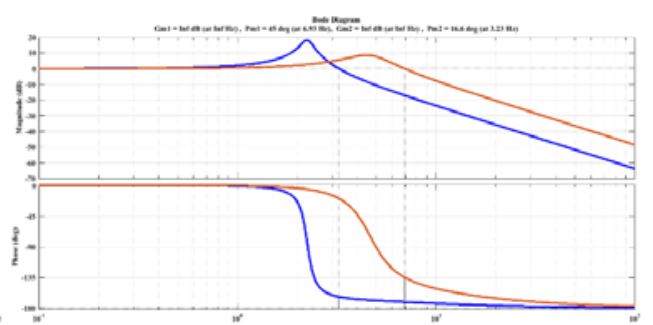

(b)

Figure 7. (a) Bode-diagram of the OL system (b) Bode-diagram of the CL system

\section{RESULT AND ANALYSIS}

The TAB average model was simulated with Matlab/Simulink. The simulation results of the system response to step load changes agree well with the circuit-based component-level simulation. The simulation results will be in figure 8 and 9, by using MATLAB / Simulink. The steady state voltage and current wave forms are shown in figure 8 , with operating pints.
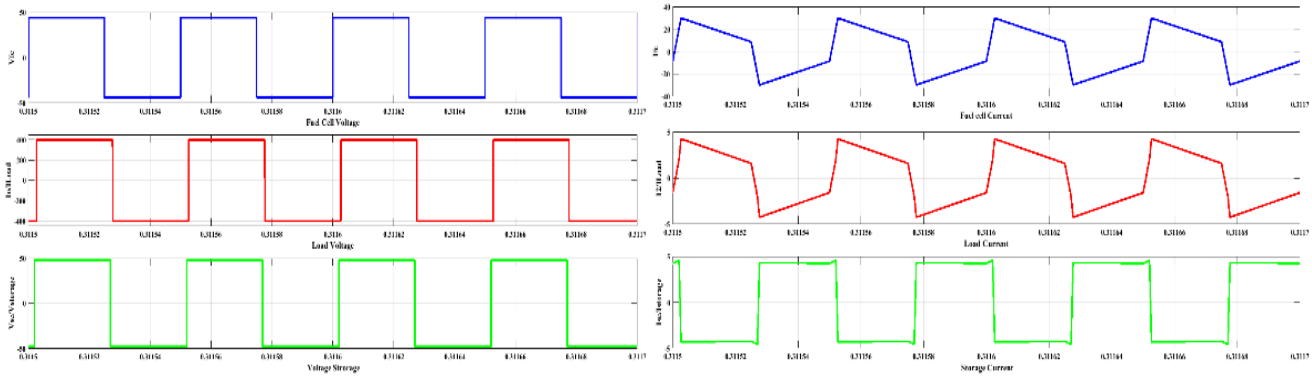

Figure 8. Voltage and current waves at transformer end for operating point $\phi_{12}=19.5^{\circ}$ and $\phi_{13}=14.5^{\circ}$

The TAB is modeled under small signal modeled, and simulation results are shows in figure 9. There are three major parts in the case of TAB configuration. They are the input bridge, the high frequency transformer and the two output bridges. These bridges are full bridge configuration and are controlled by

Power flow management of triple active bridge for fuel cell application (Nageswara Rao Kudithi) 
Phase Shift Modulation with 50\% duty cycle. The control signals are generated and applied to the bridges to make the input bridge as the leading bridge and the output bridges are as the lagging bridge to ensure the power from the input to the output. The switching frequency has been selected as $20 \mathrm{kHz}$ keeping the limitations on the magnetic core materials in mind. The waveform ensures the operation of TAB and the input power transfer to the output and depicts the primary voltage, phase and level shifted secondary voltages with their respective currents. The various values assumed in the modeling are shown in table 1.
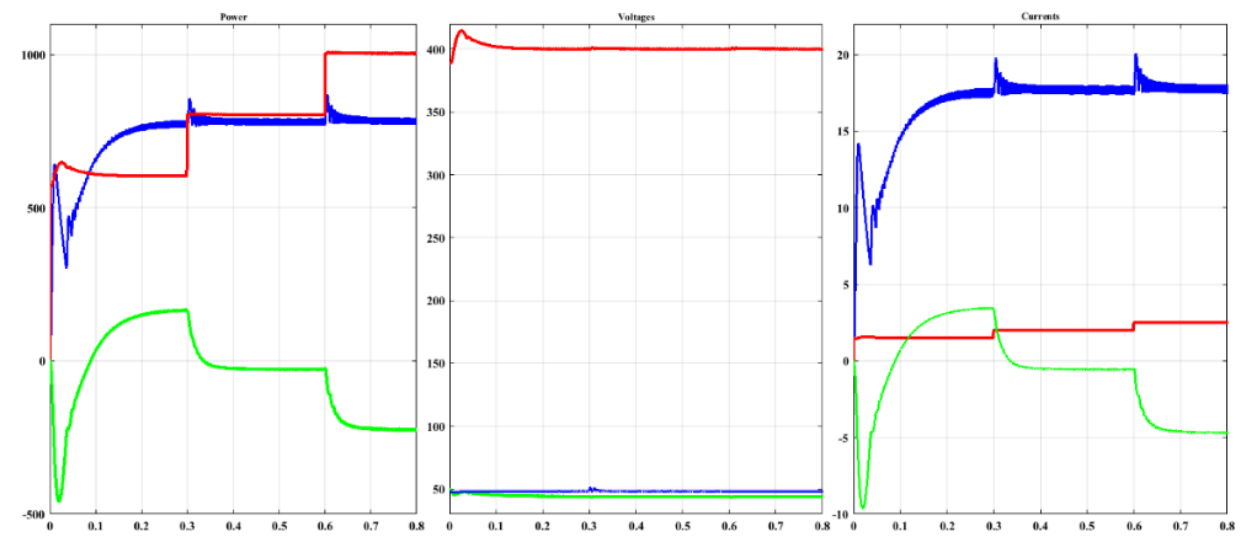

Figure 9. Input and output voltage and currents for load $600 \mathrm{~W}$ to $800 \mathrm{~W}$ and to $1000 \mathrm{~W}$

\section{CONCLUSION}

TAB considered as interface power electronic circuit system for fuel cell applications and average small signal model has been developed for it with help of DAB model. Simulations are done by using MATLAB/Simulink power system block sets. A dual PI controller has been proposed and developed for system stability under the desired output and varies loads using ESOM with DC load variations of 600W to $1000 \mathrm{~W}$ and $800 \mathrm{~W}$ as shown in Figure 9, and the maximum ripple in the fuel cell current $\left(\mathrm{I}_{\mathrm{fc}}\right)$ is found to be nearly $2 \mathrm{~A}$, which is within the safe range for fuel cell operation.

\section{REFRENCES}

[1] Ren21 R. "Global Status Report. REN21 Secretariat," Paris. 2016.

[2] Hasni N, Abd-Rahman R, Ahmad H, Jamail N, Kamaruddin M, Ridzwan S. "Investigation of potential grounding compound for portable applications", International Journal of Electrical and Computer Engineering (IJECE), Vol. 7 No. 6, pp. 3140-6, 2017.

[3] Kirubakaran A, Jain S, Nema R. "A review on fuel cell technologies and power electronic interface," Renewable and Sustainable Energy Reviews. Vol. 13, pp. 2430-40, 2009.

[4] Thounthong P, Tricoli P, Davat B. "Performance investigation of linear and nonlinear controls for a fuel cell/supercapacitor hybrid power plant," International Journal of Electrical Power \& Energy Systems. Vol. 54, pp. 454-64; 2014.

[5] Tao H, Duarte JL, Hendrix MA. "Line-interactive UPS using a fuel cell as the primary source," IEEE Transactions on Industrial Electronics. Vol. 55, pp. 3012-21, 2008.

[6] Bauman J, Kazerani M. "A comparative study of fuel-cell-battery, fuel-cell-ultracapacitor, and fuel-cell-batteryultracapacitor vehicles," IEEE Transactions on Vehicular Technology.Vol. 57, pp.760-9, 2008.

[7] Tan NML, Abe T, Akagi H. "Design and performance of a bidirectional isolated dc-dc converter for a battery energy storage system," IEEE Transactions on Power Electronics. Vol. 27, pp. 1237-48, 2012.

[8] Yu X, Starke M, Tolbert L, Ozpineci B. "Fuel cell power conditioning for electric power applications: a summary," IET Electric Power Applications. Vol.1. pp. 643-56, 2007.

[9] Tao H, Kotsopoulos A, Duarte J, Hendrix M. "Multi-Input Bidirectional DC-DC Converter Combining DC-Link And Magnetic-Coupling For Fuel Cell Systems," Industry Applications Conference, 2005 Fourtieth IAS Annual Meeting Conference Record Of The 2005: IEEE. pp. 2021-8, 2005.

[10] Kong X, Khambadkone AM. "Analysis And Implementation Of A High Efficiency, Interleaved Current-Fed Full Bridge Converter For Fuel Cell System," IEEE Transactions On Power Electronics. 2007;22:543-50.

[11] Carrasco JM, Franquelo LG, Bialasiewicz JT, Galván E, Portilloguisado RC, Prats MM, Et Al. "Power-electronic systems for the grid integration of renewable energy sources: a survey," IEEE Transactions On Industrial Electronics.Vol. 53, pp.1002-16, 2006.

Int J Pow Elec \& Dri Syst, Vol. 10, No. 2, June 2019: 672-681 
[12] Zhang N, Sutanto D, Muttaqi KM. "A review of topologies of three-port dc-dc converters for the integration of renewable energy and energy storage system," Renewable and Sustainable Energy Reviews. Vol 56, pp. 388-401, 2016.

[13] Zhao B, Song Q, Liu W, Sun Y. "Overview of dual-active-bridge isolated bidirectional dc-dc converter for highfrequency-link power-conversion system," IEEE Trans Power Electron. Vol. 29, pp. 4091-106, 2014.

[14] Inoue S, Akagi H. "A bidirectional DC-DC converter for an energy storage system with galvanic isolation," IEEE Transactions on Power Electronics. Vol. 22, pp. 2299-306, 2007.

[15] Kolar Czajw. "A novel three-phase three-port ups employing a single high-frequency isolation transformer," 2004 35th Annual IEEE Power Electronics Specialists Conference. pp. 4135-41, 2004.

[16] Jorge L. Duarte, Marcel Hendrix A, Marcelo Godoy Simões. "Three-port bidirectional converter for hybrid fuel cell systems," IEEE Transactions on Power Electronics. Vol. 22, 2007.

[17] Jain M, Daniele M, Jain PK. "A bidirectional DC-DC converter topology for low power application," IEEE Transactions on Power Electronics. Vol. 15, pp. 595-606, 2000.

[18] De Doncker RW, Divan DM, Kheraluwala MH. "A three-phase soft-switched high-power-density dc/dc converter for high-power applications," IEEE Transactions on Industry Applications. Vol. 27, pp. 63-73, 1991.

[19] Liu C, Johnson A, Lai J-S. "A novel three-phase high-power soft-switched DC/DC converter for low-voltage fuel cell applications," IEEE Transactions on Industry Applications. Vol. 41, pp. 1691-7, 2005.

[20] Chen Y-M, Liu Y-C, Wu F-Y. "Multi-input DC/DC converter based on the multiwinding transformer for renewable energy applications," IEEE Transactions on Industry Applications. Vol. 38, pp. 1096-104, 2002.

[21] Xu D, Zhao C, Fan H. "A PWM plus phase-shift control bidirectional DC-DC converter," IEEE Transactions on Power Electronics.Vol. 19, pp. 666-75., 2004

[22] Tao H, Kotsopoulos A, Duarte JL, Hendrix MA. "Transformer-coupled multiport ZVS bidirectional DC-DC converter with wide input range," IEEE Transactions on Power Electronics. Vol. 23, pp. 771-81, 2008.

[23] Camara MB, Gualous H, Gustin F, Berthon A, Dakyo B. "DC/DC converter design for supercapacitor and Battery power management in hybrid vehicle applications-polynomial control strategy," IEEE Transactions on Industrial Electronics. Vol. 57, pp. 587-97, 2010.

[24] Burke A, Miller M. "The power capability of ultracapacitors and lithium batteries for electric and hybrid vehicle applications," Journal of Power Sources. Vol. 196, pp. 514-22, 2011.

[25] Thounthong P, Rael S, Davat B. "Energy management of fuel cell/battery/supercapacitor hybrid power source for vehicle applications," Journal of Power Sources.Vol. 193, pp. 376-85, 2009.

[26] Chen Z, Mi CC, Fu Y, Xu J, Gong X. "Online battery state of health estimation based on genetic algorithm for electric and hybrid vehicle applications," Journal Of Power Sources. Vol. 240, pp.184-92, 2013.

[27] De Leon F, Martinez JA. "Dual three-winding transformer equivalent circuit matching leakage measurements," IEEE Transactions on Power Delivery.Vol. 24, pp. 160-8, 2009.

[28] Rodriguez A, Vazquez A, Lamar DG, Hernando MM, Sebastian J. "Different purpose design strategies and techniques to improve the performance of a dual active bridge with phase-shift control," IEEE Transactions on Power Electronics. Vol. 30, pp. 790-804, 2015.

[29] Zhao C, Round SD, Kolar JW. "An isolated three-port bidirectional DC-DC converter with decoupled power flow management," IEEE Transactions on Power Electronics. Vol. 23, pp. 2443-53, 2008.

[30] Tao H, Duarte JL, Hendrix MA. "Three-port triple-half-bridge bidirectional converter with zero-voltage switching," IEEE Transactions on Power Electronics. Vol. 23, pp. 782-92, 2008.

[31] James L, Andrew D. "Fuel cell systems explained," Chichster: John Wiley \& Sons Ltd. 2003.

[32] Nageswara Rao K, Somkun S. "Single phase power generation system from fuel cell" International Journal of Power Electronics and Drive Systems (IJPEDS), Vol. 9 No. 4, pp. 1676-84, 2018.

[33] Shanmugham P, Somkun S. "Modelling and simulation of dual active bridge DC-DC converters for fuel cell applications," Advanced Science Letters. Vol. 23, pp. 5112-6, 2017.

[34] Azri M, Khanipah NHA, Ibrahim Z, Rahim NA. "Fuel cell emulator with MPPT technique and boost converter," International Journal of Power Electronics and Drive Systems (IJPEDS), Vol. 8 No. 4, pp. 1852-62, 2017.

[35] Preitl S, Precup R-E. "Technical communique: an extension of tuning relations after symmetrical optimum method for PI and PID controllers," Automatica (Journal of IFAC). Vol. 35, pp. 1731-6, 1999. 